\title{
PEMBELAJARAN MATERI GERAK PADA MAKHLUK HIDUP MENGGUNAKAN LKPD SCIENTIFIC DENGAN METODE PEMBELAJARAN INKUIRI DI SMP
}

\author{
Sri Rahayu \\ Guru SMPN 03 Sungai Kunyit \\ Email: srirahayu.cs678@gmail.com
}

\begin{abstract}
Abstrak
Kurangnya pengetahuan tentang bagaimana mengimplikasikan IPA di dalam kehidupan sehari-hari, kurangnya kesiapan peserta didik untuk mengikuti pelajaran IPA dan kurangnya kemampuan IPA guru, menjadi kendala di dalam pembelajaran IPA. Tujuan penulisan makalah ini adalah untuk mendeskripsikan kondisi, bentuk RPP dan skenario pembelajaran IPA di kelas VIII SMPN 03 Sungai Kunyit, dengan menerapkan motode inkuiri, dengan tahapan sebagai berikut;(1) Guru meminta peserta didik mengamati objek yang diamati dan mengajukan pertanyaan; (2) Guru membentuk kelompok yang anggotanya 4-5 orang secara heterogen; (3) Guru memberikan peserta didik mengajukan ide/masalah tentang objek yang diamati, guru memberikan tanggapan; (4) Guru mengarahkan peserta didik mengajukan hipotesis; (5) Guru membagikan LKPD dan mengarahkan peserta didik secara berkelompok untuk mengumpulkan data dan menjawab pertanyaan pada LKPD dengan membaca referensi terkait; (6) Guru mengarahkan peserta didik untuk menguji hipotesis dengan melakukan eksperimen ; (7) Guru mengarahkan peserta didik menarik kesimpulan; (8) Guru memberikan penghargaan kepada kelompok yang memiliki nilai/poin terbaik; (9) Guru memberikan evaluasi; (10) Penutup. Dapat disimpulkan bahwa dengan diterapkannya metode pembelajaran inkuiri, dapat membuat peserta didik aktif dalam pembelajaran.
\end{abstract}

\section{Kata Kunci: Metode Pembelajaran Inkuiri, LKPD Scientific, Materi Gerak pada Makhluk Hidup, Kegiatan Pembelajaran}

\section{PENDAHULUAN}

IPA mempelajari fenomena alam, baik berupa kenyataan atau kejadian dan hubungan sebab akibatnya. IPA sepadan dengan kata sains (science), sain sendiri artinya pengetahuan. Sain kemudian diartikan sebagai natural sains, yang diterjemahkan menjadi IPA. Artinya, IPA atau sains (dalam arti sempit) sebagai disiplin ilmu yang terdiri atas physical sciences dan life sciences. Termasuk physical sciences adalah ilmu astronomi, kimia, geologi dan fisika sedangkan life sciences meliputi biologi, zoology dan fisiologi. Luasnya kajian IPA, diperlukan teknik memadukan dalam penyajiannya, apalagi pada peserta didik jenjang pendidikan dasar termasuk SMP sederajat (Parmin \& Sudarmin, 2013).

Pembelajaran IPA diharapkan mendorong peserta didik untuk bekerja dengan inisiatif sendiri, merumuskan hipotesis dan mendorong peserta didik selalu berfikir kritis. Harapannya mampu menyeimbangkan antara teori dan praktik sehingga bakat dan kecakapan dari tiap peserta didik akan tergali lebih dalam. Salah satu bentuk praktik dalam pembelajaran adalah melakukan praktikum di laboratorium maupun di lingkungan. Praktikum dilaksanakan untuk membuktikan teori dalam buku pelajaran.

Guru memiliki peran yang sangat penting untuk menanamkan pengetahuan dan keterampilan, sehingga guru dituntut menciptakan kondisi yang mempermudah pemahaman peserta didik, peserta didik mencoba belajar melalui pengamatan dengan melakukan eksperimen dengan menggunakan lembar kerja peserta didik (LKPD). Pengembangan bahan ajar LKPD sangat diperlukan untuk mempermudah pencapaian tujuan pembelajaran yang diharapkan. Salah satu keunggulan dari pengembangan LKPD adalah dapat di desain sesuai dengan keadaan peserta didik dan karakteristik sekolah sehingga peserta didik 
menjadi senang dan aktif dalam pembelajaran. Salah satu materi IPA yang ada di jenjang SMP yaitu gerak pada makhluk hidup, materi tersebut diajarkan pada kelas VIII semester ganjil.

Indikator pencapaian kompetensi yang diharapkan dalam materi gerak pada makhluk hidup adalah menurunkan. Pembelajaran yang dilaksanakan yakni pembelajaran konvensional atau pembelajaran yang biasa dilakukan di sekolah yakni; metode ceramah, tanya jawaab dan penugasaan. Wawancara dengan peserta didik juga menggambarkan bahwa peserta didik kesulitan dalam memahami materi tersebut. Dapat diperediksi, kesulitan pemahaman peserta didik terhadap materi pembelajaran, dikarenakan peserta didik belum mememukan cara belajar yang tepat untuknya. Ternyata beberapa yang dapat diungkapan penyebab peserta didik kurang aktif di dalam pembelajaran sehingga berdampak pada hasil belajar peserta didik adalah (1) pembelajaran yang dilakukan monoton (kurang variatif); (2) pengajaran yang dilakukan kurang mengasikkan; (3) kurang memanfaatkan peserta didik yang dianggap baik/berkemampuan lebih; dan (4) kurang menyertakan alat peraga/ media yang relevan.

Dengan demikian, guru memiliki peran penting dalam memilih motode pembelajaran yang dapat menciptakan pembelajaran yang kondusif, inovatif dam kreatif dengan pendekatan pembelajaran yang berorientasi kepada peserta didik. Guru dapat menggunakan motode pembelajaran sesuai dengan pengetahuannya. Satu diantara motode pembelajaran yang dapat diterapkan adalah motode pembelajaran inkuiri. Salah satunya yaitu dengan menggunakan lembar kerja peserta didik (LKPD) scientific yang sesuai dengan kondisi peserta didik, karakteristik sekolah dan materi ajar yang disampaikan sehingga dapat meningkatkan hasil belajar peserta didik. Penggunaan LKPD scientific dapat membantu peserta didik untuk belajar sehingga hasil yang diharapkan dapat tercapai secara efektif dan optimal.

\section{HASIL PENELITIAN DAN PEMBAHASAN}

Lokasi SMPN 03 Sungai Kunyit beralamat di Jl. Raya Sungai Dungun Kecamatan Sungai Kunyit Kabupaten Mempawah. Sekolah ini terletak di lokasi pinggir jalan raya, dekat dari pemukiman warga. Memiliki instalasi listrik dan jumlah ruang kelas yang cukup memadai, karena hanya tersedia 7 ruang kelas.

Pembelajaran yang biasa dilakukan guru saat ini, cenderung pada pembelajaran masih terfokus pada guru. Kegiatan pembelajaran yang dilakukan guru untuk beberapa bulan terakhir terkesan tidak mengalami kemajuan. Hasil Belajar peserta didik belum memuaskan. Hanya peserta didik yang berkemampuan di atas ratarata yang mengalami kemajuan belajar yang berarti.

Jumlah kelas VIII SMPN 03 Sungai Kunyit ada 3 kelas, secara keseluruhan terdiri dari 71 orang peserta didik yang terdiri dari 39 peserta didik perempuan dan 32 peserta didik laki-laki . Dari 71 orang peserta didik tersebut, 6 diantaranya tergolong peserta didik berkemampuan di atas rata-rata KKM dan 65 peserta didik berkemampuan di bawah rata-rata KKM. Sedangkan KKM IPA semester ganjil kelas VIII SMPN 03 Sungai Kunyit adalah 72.

Cara pembelajaran guru yang dilakukan pada peserta didik, cenderung dilakukan dengan metode ekspositori. Namun demikian, guru mencoba untuk memvariasikan metode pembelajaran lain yaitu dengan motode inkuiri. Dalam penulisan makalah ini guru mencoba membuat rancangan pelaksanaan pembelajaran dengan motode inkuiri dengan menggunakan LKPD scientific.

Beberapa kondisi yang diharapkan penulis adalah peserta didik mampu memahami konsep, arti dan hubungan melalui melalui proses intuitif yang akhirnya sampai kepada kesimpulan. Disamping itu, mengubah belajar yang pasif menjadi aktif dan kreatif, menemukan informasi sendiri dan meningkatkan aktivitas peserta didik dalam belajar baik secara individu maupun kelompok. Meningkatnya aktivitas peserta didik dalam pembelajaran membuat peserta didik semakin bersemangat dalam belajar sehingga hasil belajaranya meningkat. Dan jika ini dijalankan dengan tertib maka memungkinkan peserta didik terbiasa dengan beberapa karakter yang dikembangkan.

\section{KESIMPULAN DAN SARAN Kesimpulan}

Berdasarkan paparan dari pembahasan dapat disimpulkan sebagai berikut:

1. Peserta didik kelas VIII SMPN 03 Sungai Kunyit memerlukan LKPD scientific pada 
metode pembelajaran inkuiri, dimana peserta didik yang berkemampuan di atas rata-rata berkerjasama bersama dengan peserta didik yang berkemampuan di bawah rata-rata, dalam memahami materi gerak pada makhluk hidup. Selanjutnya, diharapkan memiliki kemudahan dalam memahami konsep sehingga dapat meningkatkan hasil belajar.

2. RPP IPA pada materi gerak pada makhluk hidup dengan menggunakan LKPD scientific pada metode pembelajaran inkuiri di kelas VIII SMPN 03 Sungai Kunyit, pada kegiatan inti dengan tahapan sebagai berikut; (1) Guru meminta peserta didik mengamati objek yang diamati dan mengajukan pertanyaan; (2) Guru membentuk kelompok yang anggotanya 4 - 5 orang secara heterogen; (3) Guru memberikan peserta didik mengajukan ide/masalah tentang objek yang diamati, guru memberikan tanggapan; (4) Guru mengarahkan peserta didik untuk mengajukan hipotesis; (5) Guru membagikan LKPD dan mengarahkan peserta didik secara berkelompok untuk mengumpulkan data dan menjawab pertanyaan pada LKPD dengan membaca referensi terkait ; (6) Guru mengarahkan peserta didik untuk menguji hipotesis dengan melakukan eksperimen; (7) Guru mengarahkan peserta didik untuk menarik kesimpulan; (8) Guru memberikan penghargaan kepada kelompok yang memiliki nilai/poin terbaik; (9) Guru memberikan evaluasi; (10) Penutup.

3. Dalam skenario pelaksanaan pembelajaran menggunakan metode pembelajaran inkuiri, dimungkinkan dapat menciptakan pembelajaran aktif. Hal ini disebabkan pelaksanaan pembelajaran yang dilakukan dalam kelompok sehingga peserta didik lebih dominan dalam proses pembelajaran. Peserta didik dapat menjadi lebih termotivasi dalam pembelajaran karena menggunakan LKPD Saran scientific pada metode pembelajaran inkuiri.

Berdasarkan pembahasan dan kesimpulan di atas, dapat disarankan beberapa hal sebagai berikut.

1. Mengajar menggunakan LKPD scientific pada metode pembelajaran inkuiri, ketepatan pembagian anggota kelompok peserta didik yang heterogen dari segi kemampuan intelektual, jenis kelamin, maupun kemampuan kerjasamanya. Dengan demikian hasil yang diharapkan dari diterapkannya metode pembelajaran tersebut dapat maksimal.

2. Guru hendaknya menguasai materi pembelajaran dan benar-benar memahami metode pembelajaran yang diterapkannya, agar dapat mengatasi kendala yang mungkin terjadi di dalam kegiatan pembelajaran.

\section{DAFTAR PUSTAKA}

Ahmadi, F. 1999. Psikologi Umum. Bandung: Pustaka Sutera.

Bistari. 2015. Mewujudkan Penelitian Tindakan Kelas (Kenaikan Pangkat Bagi Guru). Pontianak: PT. Ekadaya Multi Inovasi.

Johar. 2006. Strategi Belajar Mengajar. Banda Aceh: Universitas Syiah Kuala.

Kemendikbud. 2013. Konsep Pendekatan Scientific. Jakarta: Badan pengembangan Sumber Daya Manusia, Pendidikan dan Kebudayaan.

Kemendikbud. 2017. Ilmu Pengetahuan Alam Kelas VIII Semester 1 . Jakarta: Pusat Kurikulum dan Perbukuan, Balitbang, Kementerian Pendidikan dan Kebudayaan.

Machin. 2014. Implementasi Pendekatan Saintifik, Penanaman Karakter dan Konservasi pada Pembelajaran Materi Pertumbuhan. Indonesia: Journals Unnes Pendidikan IPA.

Roehaeti, E.,E, Widjajanti dan R.T. Padmaningrum. 2012. Pengembangan Lembar Kerja Siswa Mata Pelajaran Sains Kimia Untuk SMP Kelas VII, VIII dan IX. Artikel Penelitian.

Sardiman. 2005. Interaksi dan Motivasi Belajar Mengajar. Jakarta: PT. Raja Grafindo Persada.

Sudarmin. 2011. Materi Kuliah IPA Terpadu, Semarang: Prodi Pendidikan IPA FMIPA UNNES.

Suryosubroto. 2002. Proses Belajar Mengajar di Sekolah. Jakarta: Rinneka.

Trianto. 2010. Model Pembelajaran Inovatif, Progresif Konsep, Landasan dan Implementasinya pada KTSP. Jakarta: Kencana.

Prastowo, A. 2012. Panduan Kreatif Membuat Bahan Ajar Inovatif. Yogyakarta: Diva Pres. 
Widjajanti. 2008. Kualitas Lembar Kerja Siswa. Yogyakarta: UNY.

Widodo, W. 2016. Buku Guru Ilmu Pengetahuan Alam. Jakarta: Kementrian Pendidikan dan Kebudayaan Republik Indonesia.
Winkel, W.S. 1996. Psikologi Pengajaran. Jakarta: Gramedia. 